Мазур Н. О., к.е.н., доцент (Національний університет водного господарства та природокористування, м. Рівне)

\title{
ГАРМОНІЗАЦІЯ ІНТЕРЕСІВ СУБ'ЄКТІВ СОЦІАЛЬНО-ТРУДОВИХ ВІДНОСИН НА ОСНОВІ ЗАПРОВАДЖЕННЯ ГНУЧКИХ РЕЖИМІВ РОБОЧОГО ЧАСУ
}

На основі вивчення зарубіжного досвіду регулювання робочого часу найманих працівників визначено можливості застосування гнучких графіків робочого часу на вітчизняних підприємствах як інструменту соціального партнерства. Обґрунтовано доцільність запровадження режимів організації робочого часу на засадах гнучкості як альтернативу жорсткому графікові робочого часу, сформованому на принципах патерналізму. Ідентифіковано основні умови та вигоди запровадження вільних графіків робочого часу для роботодавців і найманих працівників з метою гармонізації їхніх інтересів. Ключові слова: гнучкий графік робочого часу, робочий час, соціальне партнерство, соціально-трудові відносини.

Діяльність будь-якого сучасного підприємства обумовлюється постійними процесами приймання, внутрішнього переміщення, переведення, звільнення, навчання, перепідготовки, підвищення кваліфікації, професійного зростання і просування працівників. Тобто відбувається постійний рух персоналу, що забезпечує відповідність його складу потребам організації.

На всіх етапах розвитку суспільства основною метою власників засобів виробництва завжди було досягнення якомога вищих фінансових результатів, а основним мотивом найманих працівників - якомога вищий розмір заробітної плати. Однак характер відносин між роботодавцем і найманим працівником визначається також значною кількістю нематеріальних чинників, найвагомішим з яких $€$ режим робочого часу. Сприятливий графік роботи здатний забезпечити задоволення людських потреб як фізіологічного, так і соціальнопсихологічного рівня та сприяти покращенню результатів діяльності кожного окремого працівника, а отже й підприємства в цілому. Дослідження й запровадження ефективних режимів робочого часу на засадах саморегулювання та гнучкості набуває особливої актуальності в контексті прагнення України бути демократичною державою, в якій людина визнається найвищою соціальною цінністю. 
Концепція гнучких форм організації робочого часу стає все популярнішою в розвинених країнах, а в останні роки до них звертаються й українські теоретики і практики в галузі соціально-трудових відносин та управління персоналом, однак без детального дослідження їхньої сутності й можливостей запровадження. Зокрема, на сьогодні досить мало уваги приділено вивченню потенціалу вільних режимів робочого часу щодо забезпечення реалізації інтересів роботодавців та найманих працівників на принципах соціального партнерства.

Регулювання робочого часу на більшості вітчизняних підприємств здійснюється на засадах патерналізму. Практика, коли працівники не підпорядковуються жорсткому графіку робочого часу і не перебувають під постійним наглядом, сприймається нашими роботодавцями здебільшого неоднозначно і часто викликає супротив. Тому постає завдання дослідження гнучких форм організації робочого часу в контексті можливостей їх використання у вітчизняних організаціях з метою гармонізації інтересів роботодавців і найманих працівників.

Регулювання робочого часу є однією з головних складових формування та реалізації соціально-трудових відносин як на рівні окремого підприємства, так і на рівні конкретної галузі та національної економіки в цілому, дієвим чинником організації праці й стимулювання найманих працівників, універсальним вимірником затрат їхньої праці. Регламентації тривалості робочого часу приділено значну увагу у нормативно-правових актах у сфері праці та в колективних договорах і угодах усіх рівнів. Регулювання співвідношення між часом роботи і часом відпочинку в практичному втіленні знаходить відображення в таких елементах його організації, як встановлення початку і закінчення роботи, часу і тривалості перерви на відпочинок і харчування, тривалості робочого дня (зміни), порядку чергування працівників у змінах та інших складових внутрішнього трудового розпорядку, що прийнято трактувати як режим робочого часу.

Для працівників більшості вітчизняних підприємств, установ та організацій режим робочого часу є саме тим елементом соціальнотрудових відносин, який все ще реалізується переважно на принципах патерналізму. Зокрема передбачено п'яти- або шестиденний робочий тиждень, чітко регламентовані внутрішнім трудовим розпорядком початок і закінчення робочого дня, час і тривалість обідньої перерви, кількість змін протягом облікового періоду, тобто традиційний жорсткий графік робочого часу. 
У соціально орієнтованій ринковий економіці регулювання робочого часу відбувається на основі гармонізації фізичних і психологічних особливостей працівника та соціальних і економічних чинників стадії розвитку суспільства. Тому в розвинених країнах все більшої популярності набуває запровадження режимів робочого часу на засадах саморегулювання, що надає їм певної гнучкості. У світовій практиці управління персоналом виділяють такі альтернативні жорсткому режимові моделі організації робочого часу, як неповний робочий час, поділ робочого місця між кількома працівниками, робота за викликом, змінна робота, рахунки робочого часу, робочий час, заснований на взаємній довірі, аморфний робочий час, телеробота [1], більшість з яких ґрунтуються на реальних принципах соціального партнерства i $€$ для вітчизняних підприємств ефективною альтернативою жорсткому графікові робочого часу.

Найвищий потенціал щодо гармонізації відносин між роботодавцями і найманими працівниками притаманний гнучкому (вільному, ковзкому) режимові робочого часу (Flexible Working Hours, Flextime), коли працівникові надається право вибору початку і закінчення робочого дня за умови відпрацювання загальної кількості робочих годин.

Офіційно гнучкі графіки робочого часу вперше були застосовані під натиском профспілок у Німеччині та Швеції в 60-х роках XX ст. Згодом подібну практику запровадили в США, Швейцарії, Норвегії, Великобританії та інших розвинених країнах. В Україні таку форму організації робочого часу використовують досить рідко. Роботодавці не висловлюють жодного захоплення від ідеї надання працівникам можливостей використовувати робочий день на власний розсуд. Працівники ж мають мало уявлення про таку форму роботи через низький рівень інформованості.

Водночас гнучкий графік робочого часу може бути запроваджено для працівників будь-яких професій і посад з чітко визначеними завданнями та обов'язками, значна частина яких виконується в індивідуальному порядку, без узгодження з колегами, тобто праця яких не потребує постійної присутності у чітко визначені правилами внутрішнього трудового розпорядку години. Враховуючи особливості функціонування конкретної організації, доцільно визначити фіксовану частину («ядро») робочого часу, коли працівник обов'язково має бути присутнім на робочому місці, а далі надати можливість регулювати власний час, встановивши період найбільш пізнього початку і найбільш раннього закінчення роботи. Зважаючи на те, що серед завдань і обов'язків будь-якого працівника на будь-якому робочому місці (посаді) $€$ такі, що їх можна виконати лише за умови прямої взає- 
модії з іншими людьми (колегами, зовнішніми клієнтами, представниками контролюючих органів, виконання наставницьких функцій тощо), для загальної зручності час обов'язкової присутності працівника на роботі доцільно встановити ближче до середини традиційного робочого дня. В межах змінної частини робочого часу працівники можуть виконувати функції, які не потребують безпосередньої взаємодії з іншими людьми (складання звітності; вивчення фахової літератури, нормативно-методичних та довідкових матеріалів; оформлення документації відповідно до професійних чи посадових обов'язків; виготовлення продукції та виконання робіт, що не вимагає прямого контакту з іншими працівниками). Умовою має бути відпрацювання визначеної внутрішніми нормативними документами тривалості робочого часу таким чином, щоб в цілому була виконана норма, встановлена у розрахунку на день або на обліковий період.

При застосуванні вільних графіків роботи можливе створення i використання рахунків робочого часу [2] (банку часу [3, С. 188]), що дозволить надати ще більшої гнучкості організації індивідуального робочого часу конкретного працівника. Відпрацьований за певний обліковий період понад норму час не пропадає, а накопичується на особистому рахунку працівника і в подальшому може бути компенсований шляхом погашення заборгованості за певний період, надання відгулу або додаткової відпустки.

Вільний режим робочого часу може також передбачати поділ робочого місця між працівниками. В цьому випадку гнучка форма робочого часу для кожного із зайнятих на даному робочому місці поєднується з обов'язковою присутністю одного з них на роботі [4, С. 196]. При цьому працівникам надається право встановлювати параметри робочого часу на основі домовленості між ними, що також відповідає принципам соціального партнерства та солідарності.

Концепція поділу робочих місць (job sharing) вперше також з'явилась всередині 60-х років XX століття як спосіб поділу робочого місця між кількома працівниками й може приймати вигляд поділу робочого дня, робочого тижня або роботи через тиждень. Відповідальність працівників при цьому може бути спільною (за умови їх взаємозамінності), роздільною (коли працівники виконують незалежні функції, але за необхідності можуть заміняти один одного, наприклад, під час роботи над проектом або при вирішенні проблеми клієнта) або незалежною (працівники виконують абсолютно різні завдання, але з точки зору роботодавця працюють на одному робочому місці) [5].

Важливою перевагою гнучкого робочого часу $є$ можливість для найманого працівника і для роботодавця прийняти рішення про 
Серія «Економічні науки»

Випуск 4(84) 2018 р.

встановлення індивідуального графіка робочого часу з максимальним дотриманням принципів соціального партнерства. Завдяки запровадженню гнучких моделей робочого часу наймані працівники отримають значні можливості задоволення широкого спектра власних потреб шляхом регулювання меж між робочим часом і часом відпочинку. Співробітники можуть не примушувати себе працювати всупереч власним біоритмам, уникаючи таким чином хронічної втоми, що спричиняє різноманітні захворювання та відразу до роботи. При використанні вільних графіків можливим стає виконання складних завдань в ту частину дня, яка $€$ оптимальною для конкретного працівника. Самостійність у плануванні власного робочого часу також позитивно впливає на фізичний та психічний стан будь-якої людини. Працівники, які працюють на основі гнучких графіків, мають більше вільного часу та можливостей для задоволення особистих потреб за межами підприємства. Роботодавець, запровадивши гнучкий режим робочого часу, може отримати всі можливі переваги від використання цього високоефективного стимулу шляхом зменшення втрат робочого часу у зв'язку із запізненнями на роботу та відпрошуваннями через сімейні обставини, проблеми зі здоров'ям та добиранням до місця роботи, покращення соціально-психологічного клімату, скорочення плинності персоналу (рисунок).

Окремої уваги заслуговує така суттєва вигода для роботодавця, як зниження плинності кадрів на конкретному підприємстві. Зростання плинності працівників негативно впливає на рівень та динаміку результатів їхньої праці та інших показників діяльності підприємства. Основні втрати підприємства від плинності персоналу включають: 1) втрати, зумовлені простоями обладнання через утворення незаповнених робочих місць, зниженням якості продукції, погіршенням обслуговування обладнання і зниженням продуктивності праці працівників, які звільняються з підприємства; 2) втрати від зниження продуктивності та якості результатів праці у період адаптації працівників на новому робочому місці; 3) витрати на виплату вихідної допомоги, допомоги по безробіттю; 4) витрати на набір, підготовку, оформлення прийому та звільнення працівників [6, С. 70-71]. У працівників, які готові змінити місце роботи, продуктивність праці на 3,6\% нижча, а тривалість прогулів в 2,6 раза більша ніж у постійних працівників. На один акт прийому-звільнення спостерігається в середньому 12 робочих днів неврахованих втрат робочого часу, зумовлених невиробничими витратами часу на оформлення документів, освоєння нових умов праці, входження в колектив тощо [7, С. 149].

За оцінками науковців за рахунок запровадження гнучкого робочого часу продуктивність праці в окремих випадках може зростати до 20\% [5]. Крім того, організації, які пропонують таку форму зайнятості, мають більше конкурентних переваг на ринку праці в очах 
потенційних працівників, у тому числі висококваліфікованих.

\begin{tabular}{|l}
\hline Необхідні умови для запровадження гнучкого режиму робочого часу: \\
$\checkmark \quad$ точний облік відпрацьованого часу; \\
$\checkmark$ наявність критеріїв оцінювання результатів роботи працівника; \\
$\checkmark$ \\
встановлення періоду найбільш пізнього початку і найбільш раннього закінчен- \\
ня роботи та «ядра» робочого часу для конкретних категорій працівників; \\
$\checkmark \quad$ високий рівень самоорганізації, відповідальності, внутрішньої дисципліни, ком- \\
петентності та професіоналізму працівників.
\end{tabular}

\begin{tabular}{|l|l|}
\hline \multicolumn{1}{|c|}{ ГНУчКИЙ РЕЖИМ РОБОчого чАСУ, } \\
+ використання рахунків робочого часу; \\
+ поділ робочого місця між працівниками
\end{tabular}

Рис. 1. Гармонізація інтересів основних суб'єктів соціально-трудових відносин на основі запровадження гнучких режимів робочого часу

Джерело: розроблено автором 
Серія «Економічні науки»

Випуск 4(84) 2018 р.

Застосування гнучкого режиму робочого часу в Україні законодавчо майже не регламентоване і на сьогодні $є$ справою доброї волі найманих працівників та роботодавця, має встановлюватися колективним договором чи правилами внутрішнього трудового розпорядку за згодою між власником та профспілковим комітетом або іншим органом, уповноваженим представляти інтереси найманих працівників, та вводитися наказом керівника підприємства. Обов'язковою умовою ефективного використання гнучкого графіка робочого часу $є$ точний облік відпрацьованого часу.

Основна перевага гнучкої форми організації робочого часу полягає в тому, що вона, створюючи відчуття бажаної для кожної особистості свободи і самостійності у прийнятті рішень, зорієнтована перш за все на результат роботи, як кількісний, так і якісний, а не на «вбивання» часу на робочому місці, і таким чином відіграє вагому мотивуючу роль у прагненні до успіху та ефективного використання робочого часу, що $є$ однією з основних передумов гармонізації інтересів основних суб'єктів соціально-трудових відносин. Вільні режими робочого часу позитивно впливають на фізичний і психологічний стан індивіда за рахунок мінімізації контролю за процесом його діяльності та можливості виконувати робочі функції згідно з власними біоритмами, розширюють можливості для задоволення особистих потреб за межами підприємства. Скорочуються непродуктивні витрати та втрати часу, пов'язані зі здоров'ям, поганою погодою, проблемами $з$ транспортом. Запровадження гнучких режимів робочого часу здатне вирішити чималу кількість завдань щодо його оптимізації, ресурсозбереження, конкурентної привабливості роботодавців та мотивації персоналу й тим самим сприяти гармонізації інтересів найманих працівників та власників підприємства.

У випадку поступового запровадження вільних графіків робочого часу для окремих груп працівників необхідне проведення роз'яснювальної роботи серед персоналу та якомога менший часовий лаг між переведенням на альтернативні форми організації робочого часу різних груп працівників. У разі небажання працівника працювати на умовах гнучкого графіка, він може повернутися до попереднього жорсткого графіка роботи, адже вільний режим підходить не для кожної особистості. Робота за гнучким графіком вимагає високого рівня самоорганізації, відповідальності, внутрішньої дисципліни, компетентності та професіоналізму, щоб вірно розставити пріоритети та виконати завдання якісно і в установлений термін. Всі ці моменти мають бути передбачені колективним договором та локальними нормативними документами, які регулюють трудові відносини, пов'язані з робочим часом. 
Саморегулювання робочого часу $є$ прямим чинником гармонізації інтересів сторін соціально-трудових відносин на принципах соціального партнерства, розвитку та ефективного використання трудового потенціалу як кожного окремого працівника, так і потенціалу колективу підприємства й суспільства в цілому. Крім вагомих можливостей стимулювання найманих працівників до підвищення результативності праці гнучкі моделі робочого часу здатні сприяти залученню до трудової діяльності таких категорій економічно пасивного населення, як учні й студенти денної форми навчання, а також особи, зайняті веденням домашнього господарства, вихованням дітей, доглядом за хворими або іншими соціальними функціями.

1. Цыганова И. ФРГ: гибкие режимы работы. Человек и труд. 2008. № 2. С. 67-70. 2. Полянина, А. Мотивация свободным временем. Управление персоналом. 2008. № 1. С. 5. 3. Колот А. М. Мотивація, стимулювання і оцінка персоналу : навч. посібник. К. : КНЕУ, 1998. 224 с. 4. Тучков А. И. Экономика труда : учебное пособие. М. : ИКФ «ЭКМОС», 2001. 240 с. 5. Костюнина Г. М. Гибкие формы занятости: мировой опыт и практика Сингапура. Труд за рубежом. 2004. № 2. С. 95-110. 6. Ерохина Р. И., Самраилова Е. К. Анализ трудовых показателей на предприятии : учеб. пособие. М. : Издательство «МИК», 2000. 160 с. 7. Гиляровская Л. Т. Методология и методика системного анализа материального стимулирования труда в объединениях (предприятиях). Воронеж : Издательство Воронежского университета, 1985. 279 с.

\section{REFERENCES:}

1. Tsyhanova I. FRH: hibkie rezhimy raboty. Chelovek i trud. 2008. № 2. S. 6770. 2. Polianina, A. Motivatsiia svobodnym vremenem. Upravlenie personalom. 2008. № 1. S. 5. 3. Kolot A. M. Motyvatsiia, stymuliuvannia i otsinka personalu : navch. posibnyk. K. : KNEU, 1998. 224 s. 4. Tuchkov A. I. Ekonomika truda : uchebnoe posobie. M. : IKF «EKMOS», 2001. 240 s. 5. Kostiunina H. M. Hibkie formy zaniatosti: mirovoi opyt i praktika Sinhapura. Trud za rubezhom. 2004. № 2. S. 95-110. 6. Erokhina R. I., Samrailova E. K. Analiz trudovykh pokazatelei na predpriiatii : ucheb. posobie. M. : Izdatelstvo «MIK», 2000. 160 s. 7. Hiliarovskaia L. T. Metodolohiia i metodika sistemnoho analiza materialnoho stimulirovaniia truda $v$ obedineniiakh (predpriiatiiakh). Voronezh : Izdatelstvo Voronezhskoho universiteta, 1985. $279 \mathrm{~s}$.

Рецензент: д.е.н., професор Савіна Н. Б. (НУВГП) 
HARMONIZATION OF INTERESTS OF SOCIAL AND LABOUR RELATIONS PARTIES BASED ON THE IMPLEMENTATION OF FLEXIBLE WORKING HOURS

Favourable schedule is able to meet the human needs of different levels and to contribute improving the results of each hired worker and, therefore, of the whole enterprise. However, today very little attention is devoted to the study of the potential of free working-time regimes in the context of ensuring the realization of the interests of employers and employees on the principles of social partnership. The regulation of working time at most domestic enterprises is based on the principles of paternalism. The practice where workers are not subject to a rigid schedule of working hours and are not under constant supervision is often perceived by employers ambiguously and often counterproductive. Therefore, the task is to study flexible forms of working time organization on the possibilities of their use in domestic organizations to harmonize the interests of employers and employees.

Based on the study of foreign experience in regulating working hours of employees, the possibility of using flexible working time schedules at domestic enterprises as an instrument of social partnership is identified. The expediency of introducing modes of work organization based on flexibility as an alternative to hard working time, formed on the principles of paternalism, is substantiated. The basic conditions and benefits of introducing free time schedules for employers and for employees to harmonize their interests are identified.

The main advantage of the flexible form of working time is creating a sense of the desired individual freedom and independence in decisionmaking. It is oriented primarily to the result of work and thus plays a strong motivating role in the pursuit of success and effective use of working time, which is one of the main preconditions for harmonizing the interests of the main parties of social and labour relations. The introduction of flexible working time regimes can solve a considerable number of tasks related to its optimization, resource conservation, competitive attractiveness of employers, and motivation of staff, and thus contribute to the harmonization of the needs of hired workers and the interests of business owners and society as a whole. Keywords: stages Flexible Working Hours, working time, social partnership, social and labour relations. 
Мазур Н. А., к.э.н., доцент (Национальный университет водного хозяйства и природопользования, г. Ровно)

ГАРМОНИЗАЦИЯ ИНТЕРЕСОВ СУБЪЕКТОВ СОЦИАЛЬНО-ТРУДОВЫХ ОТНОШЕНИЙ НА ОСНОВЕ ПРИМЕНЕНИЯ ГИБКИХ РЕЖИМОВ РАБОЧЕГО ВРЕМЕНИ

На основе изучения зарубежного опыта регулирования рабочего времени наемных работников определены возможности применения гибких графиков на отечественных предприятиях как инструмента социального партнерства. Обоснована целесообразность введения режимов организации рабочего времени на основе гибкости в качестве альтернативы жестком графику рабочего времени, сформированному на принципах патернализма. Идентифицированы основные условия и выгоды внедрения свободных графиков рабочего времени для работодателей и наемных работников $C$ целью гармонизации их интересов.

Ключевые слова: гибкий график рабочего времени, рабочее время, социальное партнерство, социально-трудовые отношения. 